\title{
MEH-PPV and PCBM Solution Concentration Dependence of Inverted-Type Organic Solar Cells Based on Eosin-Y-Coated ZnO Nanorod Arrays
}

\author{
Riski Titian Ginting, ${ }^{1}$ Chi Chin Yap, ${ }^{1}$ Muhammad Yahaya, ${ }^{1}$ and Muhamad Mat Salleh ${ }^{2}$ \\ ${ }^{1}$ School of Applied Physics, Faculty of Science and Technology, Universiti Kebangsaan Malaysia, 43600 Bangi, Selangor, Malaysia \\ ${ }^{2}$ Institute of Microengineering and Nanoelectronics (IMEN), Universiti Kebangsaan Malaysia, 43600 Bangi, Selangor, Malaysia \\ Correspondence should be addressed to Chi Chin Yap; ccyap@ukm.my
}

Received 1 August 2012; Revised 29 November 2012; Accepted 29 November 2012

Academic Editor: Manoj A. G. Nambuthiry

Copyright ( 92013 Riski Titian Ginting et al. This is an open access article distributed under the Creative Commons Attribution License, which permits unrestricted use, distribution, and reproduction in any medium, provided the original work is properly cited.

\begin{abstract}
The influence of polymer solution concentration on the performance of chlorobenzene- (CB-) and chloroform- (CF-) based inverted-type organic solar cells has been investigated. The organic photoactive layers consisted of poly(2-methoxy-5-(2-ethyl hexyloxy)-1,4-phenylenevinylene) (MEH-PPV) and (6,6)-phenyl $\mathrm{C}_{61}$ butyric acid methyl ester (PCBM) were spin coated from $\mathrm{CF}$ with concentrations of 4,6 , and $8 \mathrm{mg} / \mathrm{mL}$ and from $\mathrm{CB}$ with concentrations of 6,8 , and $10 \mathrm{mg} / \mathrm{mL}$ onto Eosin-Y-coated $\mathrm{ZnO}$ nanorod arrays (NRAs). Fluorine doped tin oxide (FTO) and silver (Ag) were used as electron collecting electrode and hole collecting electrode, respectively. Experimental results showed that the short circuit current density and power conversion efficiency increased with decrease of solution concentration for both CB and CF devices, which could be attributed to reducing charge recombination in thinner photoactive layer and larger contact area between the rougher photoactive layer and Ag contact. However, the open circuit voltage decreased with decreasing solution concentration due to increase of leakage current from $\mathrm{ZnO} \mathrm{NRAs}$ to $\mathrm{Ag}$ as the $\mathrm{ZnO}$ NRAs were not fully covered by the polymer blend. The highest power conversion efficiencies of $0.54 \pm 0.10 \%$ and $0.87 \pm 0.15 \%$ were achieved at the respective lowest solution concentrations of $\mathrm{CB}$ and $\mathrm{CF}$.
\end{abstract}

\section{Introduction}

Rapid development in enhancing the performance of organic solar cells (OSCs) for the past few years by utilizing bulk heterojunction $(\mathrm{BHJ})$ devices has enabled power conversion efficiency (PCE) up to $10.6 \%$ to be achieved [1]. In the case of $\mathrm{BHJ}$ conventional device structure, an active layer which consists of polymer donor and acceptor material is normally sandwiched between indium tin oxide (ITO) anode and aluminium (Al) cathode [2]. Poly(3,4-ethylenedioxythiophene): poly(styrenesulfonate) or PEDOT:PSS which plays role as conductive hole transport layer (HTL) is commonly introduced in between organic photoactive layer and ITO anode [3]. However, due to strong acidic nature of PEDOT:PSS, instability between the interface of ITO/PEDOT:PSS could create defect site and thus leading to deteriorated device performance $[4,5]$. Moreover, oxidation of low work function $\mathrm{Al}$ electrode $(4.28 \mathrm{eV})$ in air could also lead to instability at the interface between metal and organic photoactive layer [6]. In order to solve these issues, inverted configuration with low work function metal or metal oxides materials as electron transporting layer and high work function metal (e.g., silver, gold) as hole collection electrode have been introduced to improve the stability of the device $[6,7]$. Lately, a lot of attention towards inverted OSCs with various metal oxide nanostructures as electron transporting layer have been developed, such as $\mathrm{ZnO}$ [8-14], $\mathrm{TiO}_{2}$ [15-19], alkali-metal oxide cesium carbonate $\left(\mathrm{Cs}_{2} \mathrm{CO}_{3}\right)[20,21]$, and others [22, 23]. The environmental-friendly and low-cost $\mathrm{ZnO}$ nanorods arrays (NRAs) can be grown at low temperature (below $100^{\circ} \mathrm{C}$ ) by hydrothermal method [24]. The ZnO NRAs not only have good electron collecting and transporting property 
in the inverted OSCs hybridized with the polymer blend, but also can provide larger interface surface area to improve photocurrent and efficiency [25].

Recently, much effort has been focused on utilizing blend film of poly(3-hexylthiophene) (P3HT) and (6,6)-phenyl $\mathrm{C}_{61}$ butyric acid methyl ester (PCBM) as photoactive layer in $\mathrm{ZnO}$ NRAs-based inverted OSCs [19-23]. Various P3HT-PCBM processing parameters such as solvent selection, solution concentration, and spin coating speed have been investigated to optimize the solar cell performance $[25,26]$. Takanezawa et al. [25] reported that thicker organic photoactive layer deposited by using higher solution concentration or lower spin coating speed results in better power conversion efficiency as a consequence of improved optical absorption and short circuit current density. Meanwhile, Chou et al. [26] demonstrated that organic photoactive layer drying time could be lengthened by lowering the spin coating speed, hence leading to improved photovoltaic performance as a result of better polymer crystallinity, increased thickness, and enhanced infiltration of photoactive layer. However, little attention has been given to poly[2-methoxy-5-(2'ethylhexyloxy)-p-phenylenevinylene] (MEH-PPV) blended with PCBM as photoactive layer in the similar OSCs. MEHPPV has broad optical absorption region 400-600 $\mathrm{nm}$ and also higher hole mobility compared to electron mobility [27].

The present work reports on the effects of MEH-PPV and PCBM solution concentration on the performance of inverted-type OSCs based on Eosin-Y-coated ZnO NRAs. Eosin-Y organic dye, a low-cost alternative to expensive $\mathrm{Ru}-$ complexes dye, has good absorption property and is able to increase the wettability of $\mathrm{ZnO}$ surface [28]. Different solution concentrations of MEH-PPV and PCBM were prepared from chlorobenzene (CB) and chloroform (CF). The short circuit current density and power conversion efficiency increased, whereas the open circuit voltage decreased with the reduction of solution concentration. The optimum power conversion efficiencies of $0.54 \pm 0.10 \%$ and $0.87 \pm 0.15 \%$ were achieved at the respective lowest solution concentration of $\mathrm{CB}$ and $\mathrm{CF}$ devices.

\section{Experimental Methods}

2.1. Device Fabrication. Inverted OSCs with fluorine doped tin oxide (FTO)/Eosin-Y-coated ZnO NRAs/MEH-PPV and PCBM(1:2)/Ag structure were constructed. The FTO $(\sim 15 \Omega / \mathrm{sq})$ substrates were ultrasonically cleaned by using acetone and 2-propanol each for $15 \mathrm{~min}$. The $\mathrm{ZnO}$ seed layer was spin coated on top of precleaned substrates for 3 times from an equimolar solution $(0.2 \mathrm{M})$ of zinc acetate dehydrate $\left(\mathrm{Zn}\left(\mathrm{O}_{2} \mathrm{CCH}_{3}\right)_{2} \cdot\left(\mathrm{H}_{2} \mathrm{O}\right)_{2}\right)$ and diethanolamine (DEA) in ethanol followed by annealing at $300^{\circ} \mathrm{C}$ for one hour in air. The hydrothermal growth of $\mathrm{ZnO}$ NRA was done by immersing $\mathrm{ZnO}$ seed coated substrates into an equimolar aqueous solution $(40 \mathrm{mM})$ of zinc nitrate hexahydrate $\left(\mathrm{Zn}\left(\mathrm{NO}_{3}\right)_{2} \cdot 6 \mathrm{H}_{2} \mathrm{O}\right)$ and hexamethylenetetramine (HMT) at $90^{\circ} \mathrm{C}$ for $45 \mathrm{~min}$ in a laboratory oven. The dye coating was performed by spin coating a thin layer of Eosin-Y from a $0.3 \mathrm{mM}$ acetone solution onto ZnO NRAs. The MEH-PPV with molecular weight 40,000-70,000 $\mathrm{g} \mathrm{mol}^{-1}$ and PCBM were purchased from Sigma-Aldrich and Nano-C, respectively. MEH-PPV and PCBM (1:2 by weight) were dissolved in two different solvents, namely chloroform (CF) and chlorobenzene (CB) at various concentrations. $\mathrm{CF}$ solutions with concentration of $4 \mathrm{mg} / \mathrm{mL}$ to $8 \mathrm{mg} / \mathrm{mL}$ and $\mathrm{CB}$ solutions with concentration of $6 \mathrm{mg} / \mathrm{mL}$ to $10 \mathrm{mg} / \mathrm{mL}$ were spincoated on top of Eosin-Y-coated ZnO NRAs. The spinning speed and spinning time were fixed at $1000 \mathrm{rpm}$ and $60 \mathrm{~s}$, respectively. Finally, the silver $(\mathrm{Ag})$ contact $(200 \mathrm{~nm})$ was deposited by using magnetron sputtering under vacuum $(\sim$ $10^{-3}$ Torr) by flowing Argon (Ar) gas at $45 \mathrm{cc} / \mathrm{min}$. During sputtering process, a slow deposition rate $\sim 0.17 \mathrm{~nm} \mathrm{~s}^{-1}$ was used in order to avoid the damage of organic photoactive layer. Furthermore, in order to oxidize silver, pure oxygen gas was introduced during sputtering process into the vacuum chamber at a flow rate of $5 \mathrm{cc} / \mathrm{min}$. It was believed that oxidation of Ag will increase its work function from 4.3 to $5.0 \mathrm{eV}$, which in turn facilitate hole collection from donor materials to Ag and improve the cells performance [29]. Four devices for each solution concentration were fabricated.

2.2. Device Characterization. The absorption spectra of blend films consisted of organic photoactive layer and Eosin-Ycoated ZnO NRAs were investigated using a Perkin Elmer Lambda 900 UV-Vis spectrophotometer. The cross-sectional images of organic photoactive layer deposited on EosinY-coated ZnO NRAs were recorded by using Carl Zeiss Supra 55VP Field Emission Scanning Electron Microscope (FESEM). The surface morphology of the organic photoactive layers was investigated by using Ntegra Prima NT-MDT scanning probe microscope under ambient condition at $\% \mathrm{RH}$ $\sim 68 \%$ and room temperature $26^{\circ} \mathrm{C}$. The $J-V$ characteristics of the devices were measured with Keithley 237 SMU under illumination at $100 \mathrm{~mW} / \mathrm{cm}^{2}$ from a solar simulator with AM 1.5 G filter. The active area of the devices was defined as $0.07 \mathrm{~cm}^{2}$ by using mask. The incident photon to current conversion efficiency (IPCE) values was measured using Newport IPCE system at a chopping frequency of $10 \mathrm{~Hz}$. The above device fabrication and measurements were conducted under ambient atmosphere (without encapsulation).

\section{Results and Discussion}

Figure 1 shows the optical absorption properties of blend films of organic photoactive layer and Eosin-Y-coated $\mathrm{ZnO}$ NRAs. Broad absorption from $400 \mathrm{~nm}$ up to $600 \mathrm{~nm}$ is correlated with MEH-PPV [30], whereas absorption below $400 \mathrm{~nm}$ is contributed by PCBM and ZnO NRAs [31]. The absorption increased with solution concentration for both CF and CB. It has been reported that enhanced absorption in the long wavelength range of the polymer indicates the increase in crystallinity and hole mobility of the polymer [32]. However, the shape of absorption spectra of MEH-PPV and PCBM blend film (in the range of 400-600 nm) showed no notable changes with different solvents and solution concentration, suggesting no significant different in crystallinity and hole mobility of the polymer. The Eosin-Y-coated $\mathrm{ZnO}$ 


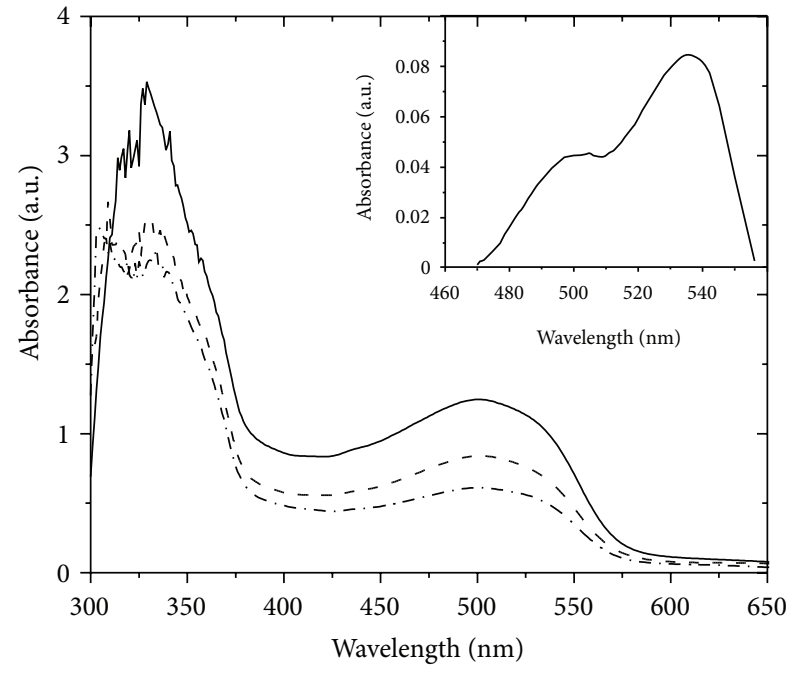

Chlorobenzene

$$
\begin{array}{ll}
- & 10 \mathrm{mg} / \mathrm{mL} \\
\ldots \ldots & 8 \mathrm{mg} / \mathrm{mL} \\
\ldots . .- & 6 \mathrm{mg} / \mathrm{mL}
\end{array}
$$

(a)

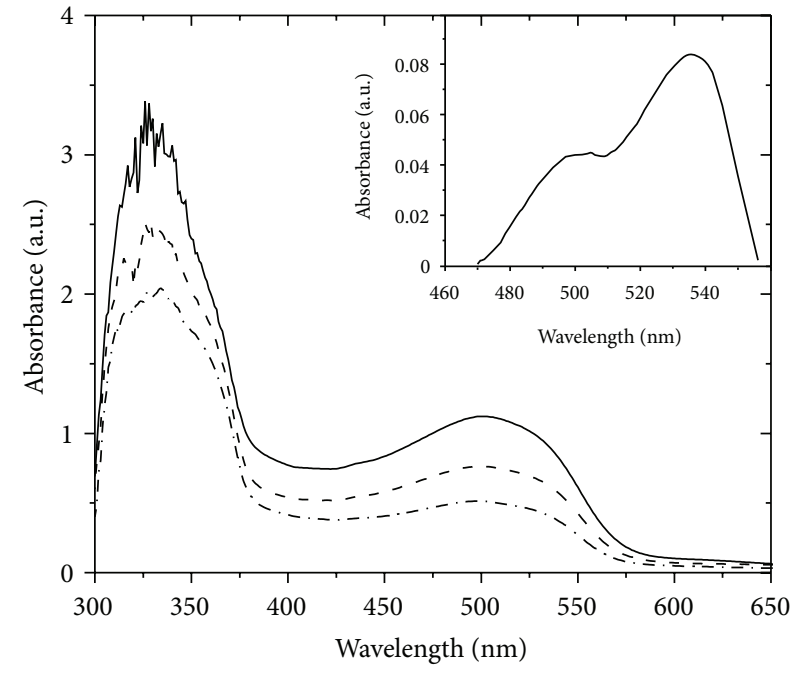

Chloroform

$\begin{array}{ll}\text { _. } & 8 \mathrm{mg} / \mathrm{mL} \\ \ldots \ldots & 6 \mathrm{mg} / \mathrm{mL} \\ \ldots . . & 4 \mathrm{mg} / \mathrm{mL}\end{array}$

(b)

FIGURE 1: The absorption spectra of blend films of Eosin-Y-coated ZnO NRAs and organic photoactive layer deposited from (a) CB and (b) $\mathrm{CF}$ solvents at various concentrations. Inset shows the absorption spectra of Eosin-Y-coated ZnO NRAs in the region 440-560 nm.

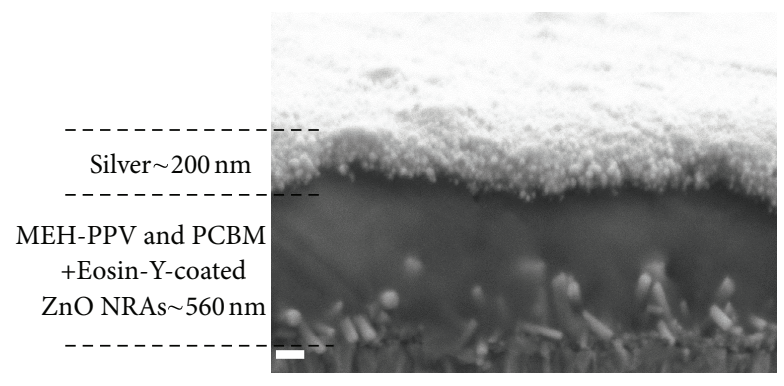

(a)

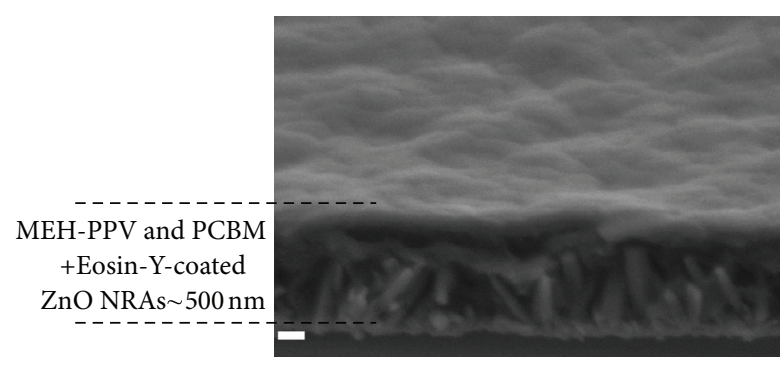

(c)

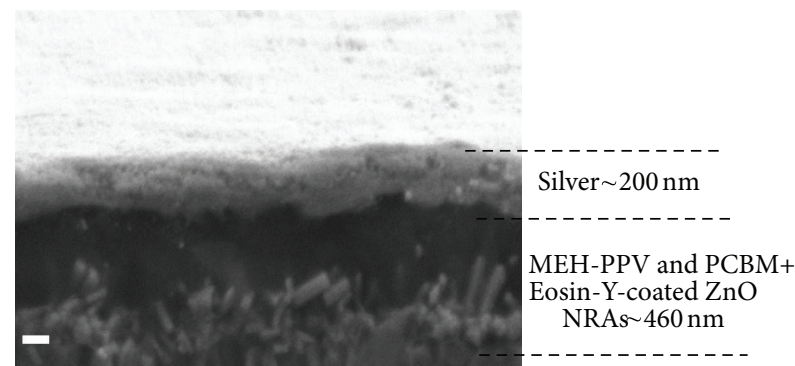

(b)

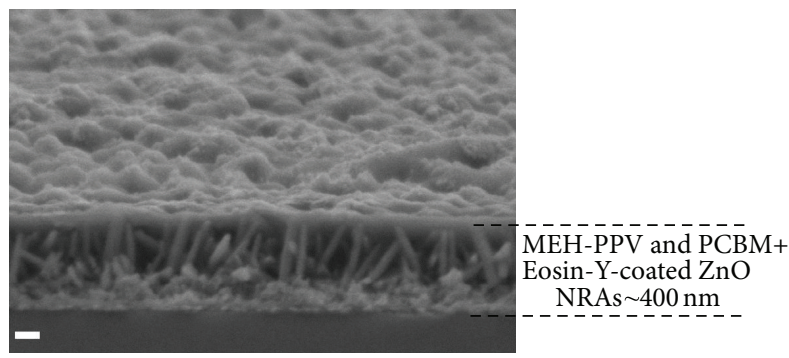

(d)

Figure 2: Cross-sectional FESEM images of devices prepared from CB at concentrations (a) $10 \mathrm{mg} / \mathrm{mL}$ (b) $6 \mathrm{mg} / \mathrm{mL}$ and prepared from CF at concentrations (c) $8 \mathrm{mg} / \mathrm{mL}$, (d) $4 \mathrm{mg} / \mathrm{mL}$ (scale bar: $100 \mathrm{~nm}$ ).

NRAs exhibited absorption in visible region from $440 \mathrm{~nm}$ to $560 \mathrm{~nm}$ (inset of Figure 1) and two absorption peaks at $500 \mathrm{~nm}$ and $530 \mathrm{~nm}$ corresponding to the monomeric and dimeric forms of Eosin-Y were observed [33]. The intensity of Eosin-Y absorption was much lower than that of MEH-PPV, suggesting Eosin-Y had a little contribution to the overall absorption of device. However, the existence of thin layer dye on top of ZnO NRAs may enhance the charge transfer efficiency at the MEH-PPV/ZnO NRAs interface and also improve the wetting state of $\mathrm{ZnO}$ NRAs [34].

Figure 2 shows typical cross-sectional images of devices prepared from $\mathrm{CB}$ and $\mathrm{CF}$ at different concentrations. $\mathrm{ZnO}$ 


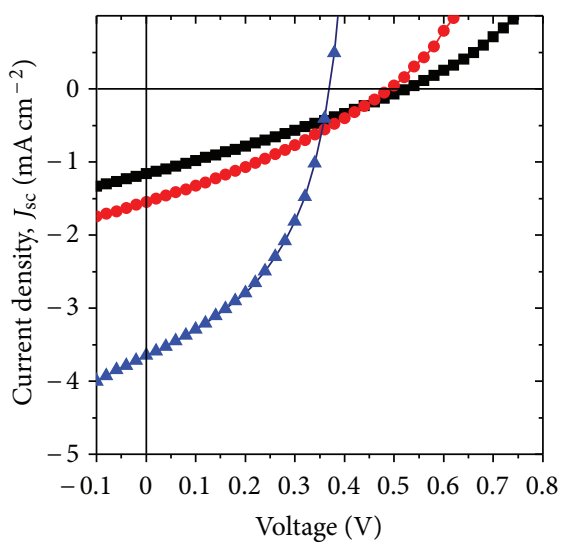

Chloroform

$\rightarrow-8 \mathrm{mg} / \mathrm{mL} \rightarrow 4 \mathrm{mg} / \mathrm{mL}$

(a)

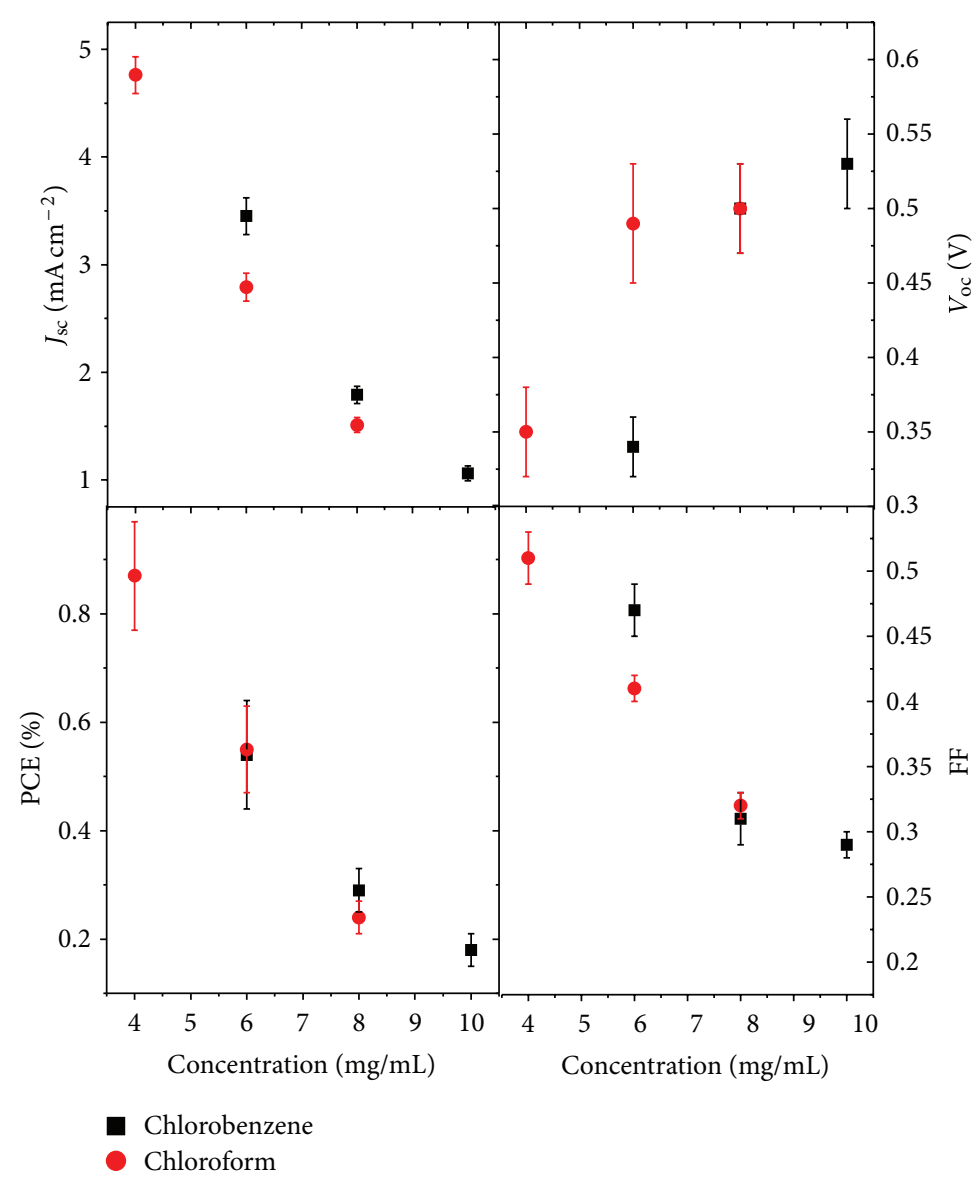

(b)

FIGURE 3: (a) $J$ - $V$ characteristics of devices prepared from different CB and CF solution concentrations, (b) photovoltaic parameters of devices as a function of solution concentration.

nanorods with diameter ranging from $50 \mathrm{~nm}$ to $80 \mathrm{~nm}$ and with length up to $300 \mathrm{~nm}$ were obtained. The total thickness of the blend films prepared from $\mathrm{CB}$ and CF reduced from $\sim 560 \mathrm{~nm}$ to $\sim 460 \mathrm{~nm}$ and from $\sim 500 \mathrm{~nm}$ and $\sim 400 \mathrm{~nm}$, respectively, with decrease of solution concentration. This is consistent with absorption result shown above where the absorption increased with increasing solution concentration, indicating formation of thicker blend film. In addition, it can be clearly seen that the infiltration of organic blend prepared from $\mathrm{CB}$ into the spacing between Eosin-Y-coated $\mathrm{ZnO}$ nanorods was better than that prepared from $\mathrm{CF}$, as indicated by the increased number of voids appeared in the interspaces between $\mathrm{ZnO}$ nanorods. The polymer prepared from a higher boiling point solvent has longer time to effectively infiltrate into the spacing between $\mathrm{ZnO}$ nanorods and gives enough time for polymer chain to self-organized [35]. Therefore, the poor infiltration could be attributed to lower boiling point of $\mathrm{CF}\left(\sim 61^{\circ} \mathrm{C}\right)$ as compared to $\mathrm{CB}\left(\sim 131^{\circ} \mathrm{C}\right)$.
The $J-V$ characteristics of typical devices under illumination of a simulated AM 1.5 sunlight at $100 \mathrm{~mW} / \mathrm{cm}^{2}$ are shown in Figure 3(a), whereas the statistical data for photovoltaic parameters obtained from a series of four individual devices for each parameter are plotted in Figure 3(b). The short-circuit current density $\left(J_{\mathrm{sc}}\right)$, fill factor $(\mathrm{FF})$ and power conversion efficiency (PCE) increased with decreasing solution concentration for both CB- and CF-based devices, whereas the open circuit voltage $\left(V_{\text {oc }}\right)$ exhibited opposite behavior. Both CB- and CF-based devices showed the highest $\mathrm{PCE}$ at respective lowest solution concentration. The device prepared from $\mathrm{CB}$ at concentration of $6 \mathrm{mg} / \mathrm{mL}$ exhibited the highest PCE of $0.54 \pm 0.10 \%$ with $J_{\mathrm{sc}}$ of $3.45 \pm 0.17 \mathrm{~mA} \mathrm{~cm}^{-2}$, $V_{\mathrm{oc}}$ of $0.34 \pm 0.02 \mathrm{~V}$ and FF of $0.48 \pm 0.02$. In the case of $\mathrm{CF}$, the highest PCE of $0.87 \pm 0.15 \%$ was achieved at the concentration of $4 \mathrm{mg} / \mathrm{mL}$, with $J_{\mathrm{sc}}$ of $4.76 \pm 0.17 \mathrm{~mA} \mathrm{~cm}^{-2}$, $V_{\text {oc }}$ of $0.35 \pm 0.03 \mathrm{~V}$, and FF of $0.51 \pm 0.02$. However, further reduction of polymer solution concentration results in very 


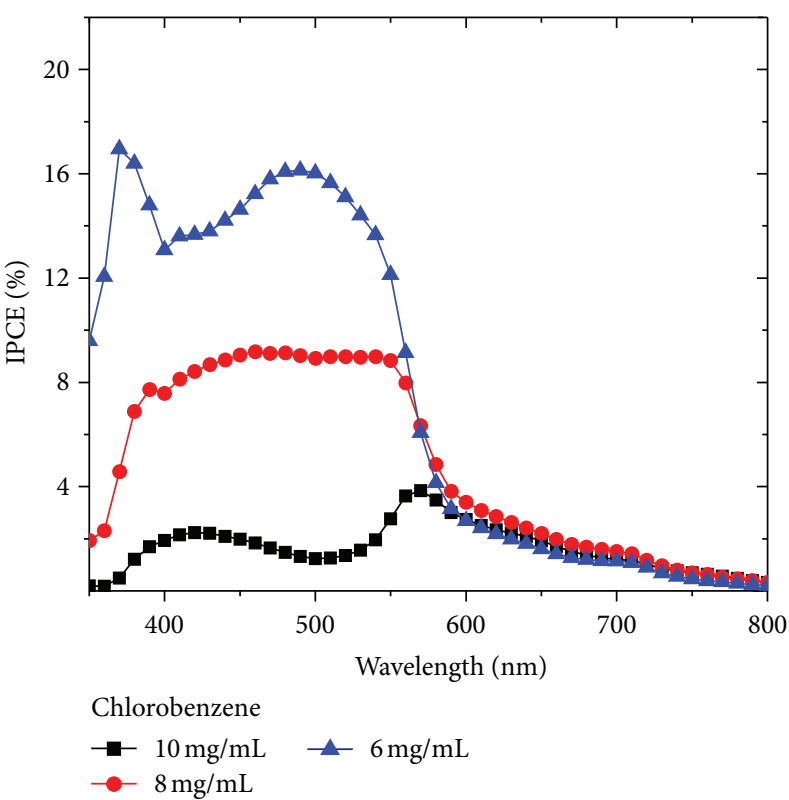

(a)

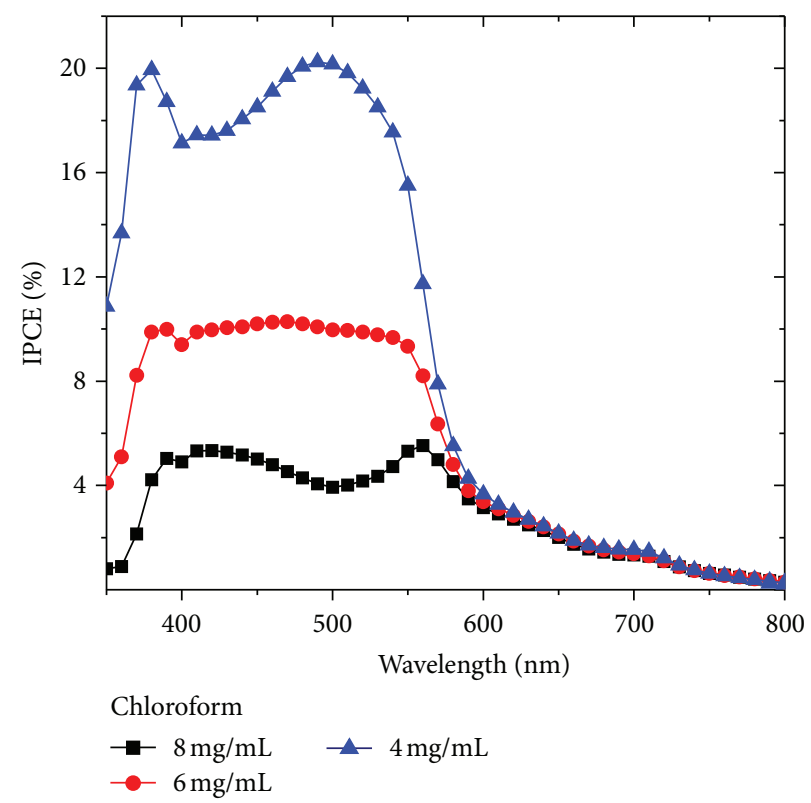

(b)

FIGURE 4: The IPCE spectra of devices prepared from different CB and CF solution concentrations.

low $V_{\text {oc }}<0.2 \mathrm{~V}$ and low $J_{\mathrm{sc}}<0.75 \mathrm{~mA} \mathrm{~cm}^{-2}$ for both $\mathrm{CB}$ and $\mathrm{CF}$ devices (not shown here). The series resistance $\left(R_{s}\right)$ and shunt resistance $\left(R_{\mathrm{sh}}\right)$ were determined from the slopes at $V_{\text {oc }}$ and $J_{\mathrm{sc}}$ in the $J-V$ curve, respectively. The enhancement of $J_{\mathrm{sc}}$ with decreasing solution concentration could be correlated with the organic photoactive layer thickness. It is generally accepted that increase in thickness results in more excitons due to higher absorption. However, the charge recombination rate also increases with thickness, resulting in lower $J_{\text {sc }}$. In contrast to study obtained on P3HT and PCBM-based inverted-type organic solar cell [25], increase in thickness did not lead to increase in $J_{\mathrm{sc}}$, but to a decrement in present work. This suggests that charge recombination process dominated the variation of $J_{\mathrm{sc}}$ with respect to thickness. It is believed that the probability of photogenerated electrons and holes to transport to ZnO NRAs and Ag, respectively, became higher with thinner photoactive layer. The $R_{s}$ decreased significantly from $397.24 \pm 30.87$ to $25.40 \pm 6.91 \Omega \mathrm{cm}^{2}$ and from 220.26 \pm 11.53 to $15.97 \pm 2.47 \Omega \mathrm{cm}^{2}$ as the polymer solution concentration reduced for $\mathrm{CB}$ and $\mathrm{CF}$ devices, respectively. This result indicates the decrease of bulk resistance across the organic photoactive layer with decreasing thickness, leading to higher number of electron and hole extracted from the device. Besides, the increase of $V_{\mathrm{oc}}$ with the solution concentration for both solvents could be due to suppression of leakage current as indicated by larger $R_{\mathrm{sh}}$. The significant decrement of $R_{s}$ with respect to $R_{\mathrm{sh}}$ leads to increment in FF. Therefore, the increase in both $J_{\mathrm{sc}}$ and FF was great enough to offset the reduced $V_{o c}$, which in turn improved the overall device performance. The overall photovoltaic performance of all devices is summarized in Table 1 .

Figure 4 shows IPCE spectra of the devices measured from wavelength 350 to $800 \mathrm{~nm}$ with maximum IPCE of $\sim 16 \%$ and $\sim 20 \%$ at $500 \mathrm{~nm}$ was achieved at respective lowest solution concentration for CB and CF device. Despite the increase of absorption with solution concentration, the opposite trend was observed from IPCE spectra. The IPCE result is consistent with $J_{\mathrm{sc}}$ which increased with decreasing solution concentration and further confirms that relatively thick organic photoactive layer on top of Eosin-Y-coated $\mathrm{ZnO}$ NRAs causes the increase of charge recombination in the organic photoactive layer and results in lower $J_{\text {sc }}$ even though the absorption increased. The IPCE spectra of the CB and $\mathrm{CF}$ devices with the highest solution concentration exhibited low photon conversion efficiency at wavelength $(500 \mathrm{~nm})$ corresponding to absorption peak of MEH-PPV. For thicker photoactive layer deposited at high solution concentration, most of the photons with wavelength close to $500 \mathrm{~nm}$ were absorbed in the region close to FTO/Eosin-Y-coated ZnO NRAs. Meanwhile, photons with wavelength away from $500 \mathrm{~nm}$ were more uniformly absorbed throughout the photoactive layer. The distortion of IPCE spectrum of thick photoactive layer indicates that photocurrent generation in the bulk region close to Ag was more efficient than that in the region close to $\mathrm{ZnO}$ NRAs [36]. This result also suggests that the probability of holes generated in the region close to $\mathrm{ZnO}$ NRAs to be trapped or recombine before reaching Ag was higher.

Figure 5 shows the topographic images of surface morphology of organic photoactive layer deposited on EosinY-coated $\mathrm{ZnO}$ NRAs with different solvent concentrations. The root mean square (rms) roughness significantly increased from 2.58 to $14.75 \mathrm{~nm}$ and from 4.11 to $17.77 \mathrm{~nm}$, respectively, as the $\mathrm{CB}$ and $\mathrm{CF}$ solution concentration decreased. The rough surface obtained from lower solution concentration indicates $\mathrm{ZnO}$ NRAs were not fully covered by polymer 


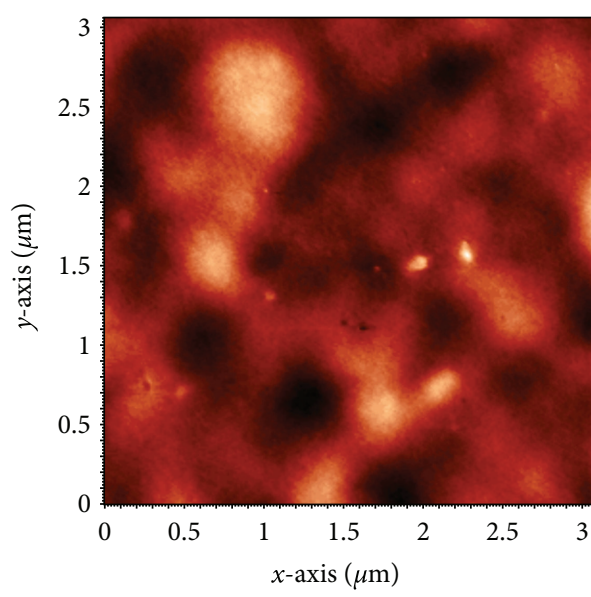

(a)

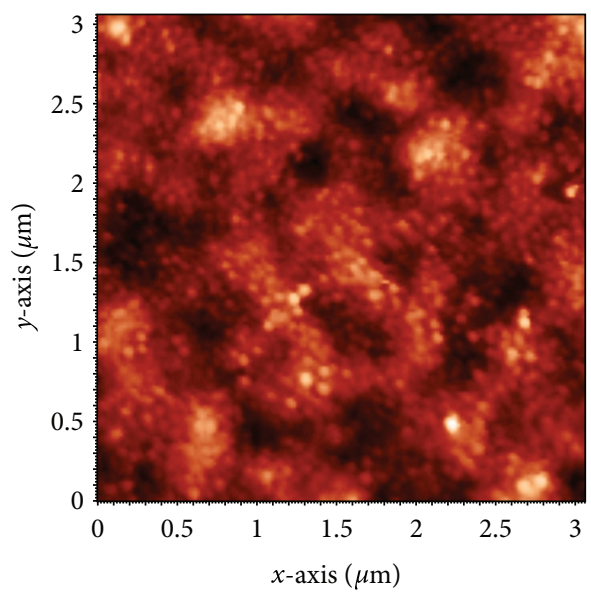

(c)
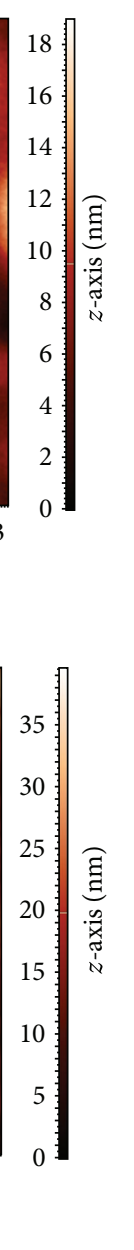

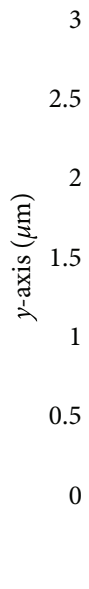

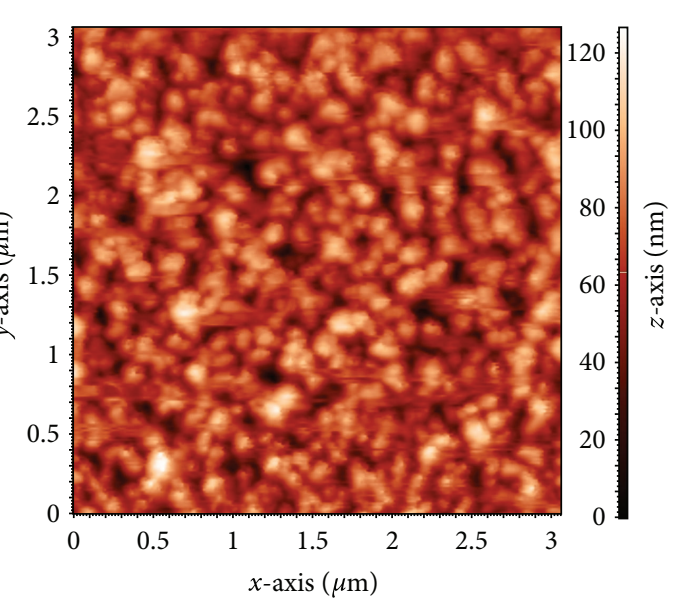

(d)

FIGURE 5: AFM images of blend films of Eosin-Y-coated ZnO NRAs and organic photoactive layer prepared from CB at concentrations (a) $10 \mathrm{mg} / \mathrm{mL}$, (b) $6 \mathrm{mg} / \mathrm{mL}$ and prepared from CF at concentrations (c) $8 \mathrm{mg} / \mathrm{mL}$, (d) $4 \mathrm{mg} / \mathrm{mL}$.

TABLE 1: Summary of photovoltaic parameters of devices at various solution concentrations.

\begin{tabular}{lcccccc}
\hline $\begin{array}{l}\text { Concentration } \\
(\mathrm{mg} / \mathrm{mL})\end{array}$ & $\begin{array}{c}J_{\mathrm{sc}} \\
\left(\mathrm{mA} \mathrm{cm}{ }^{-2}\right)\end{array}$ & $\begin{array}{c}V_{\mathrm{oc}} \\
(\mathrm{V})\end{array}$ & $\begin{array}{c}\text { PCE } \\
(\%)\end{array}$ & FF & $\begin{array}{c}R_{s} \\
\left(\Omega \mathrm{cm}^{2}\right)\end{array}$ & $\begin{array}{c}R_{\text {sh }} \\
\left(\Omega \mathrm{cm}^{2}\right)\end{array}$ \\
\hline \multicolumn{7}{c}{ Chlorobenzene } \\
\hline 10 & $1.06 \pm 0.07$ & $0.53 \pm 0.03$ & $0.17 \pm 0.03$ & $0.29 \pm 0.01$ & $397.24 \pm 30.87$ & $618.54 \pm 30.87$ \\
6 & $1.77 \pm 0.08$ & $0.50 \pm 0.03$ & $0.29 \pm 0.04$ & $0.31 \pm 0.02$ & $188.80 \pm 30.88$ & $402.77 \pm 52.21$ \\
6 & $3.45 \pm 0.17$ & $0.34 \pm 0.02$ & $0.54 \pm 0.10$ & $0.48 \pm 0.02$ & $25.40 \pm 6.91$ & $340.56 \pm 11.07$ \\
\hline 8 & & Chloroform & & $220.26 \pm 11.53$ & $526.98 \pm 46.07$ \\
6 & $1.51 \pm 0.07$ & $0.50 \pm 0.03$ & $0.24 \pm 0.03$ & $0.32 \pm 0.01$ & $51.75 \pm 6.70$ & $322.64 \pm 53.53$ \\
4 & $2.84 \pm 0.13$ & $0.49 \pm 0.04$ & $0.55 \pm 0.08$ & $0.41 \pm 0.01$ & $15.97 \pm 2.47$ & $272.05 \pm 35.96$ \\
\hline
\end{tabular}

blend. This finding is in agreement with the value of $R_{\text {sh }}$ which increased with solution concentration. Besides, this observation is also well in line with the cross-sectional FESEM images from which a wavy surface reflecting the ZnO NRAs underneath was clearly observed when organic photoactive layer was deposited from a low solution concentration. Meanwhile, the rougher surface also provides larger contact area between organic photoactive layer and metal contact, and thus leading to better charge collection efficiency $[37,38]$. Even though better photovoltaic performance can 
be achieved by depositing a thinner organic photoactive film, the film must be thick enough to prevent the direct leakage current from $\mathrm{ZnO}$ NRAs to Ag electrode.

\section{Conclusions}

The effect of solution concentration of MEH-PPV and PCBM deposited onto Eosin-Y-coated ZnO NRAs on the performance of inverted-type organic solar cell has been investigated. The short circuit current density and power conversion efficiency greatly enhanced with decrease of solution concentration for both chlorobenzene- and chloroformbased devices, mainly due to reduce of charge recombination in thinner organic photoactive layer and larger contact area between the rougher organic photoactive layer and Ag contact. In contrast, the increase of leakage current from $\mathrm{ZnO}$ NRAs to $\mathrm{Ag}$ at lower solution concentration results in decrease of open circuit voltage. The highest power conversion efficiencies of $0.54 \pm 0.10 \%$ and $0.87 \pm 0.15 \%$ were achieved at the respective lowest solution concentration of $\mathrm{CB}$ and $\mathrm{CF}$. It has been shown that the solution concentration played important role in improving performance of invertedtype organic solar cell.

\section{Acknowledgments}

This work has been carried out with the financial support of Malaysian Ministry of Science, Technology and Innovation (MOSTI) under Science Fund 03-01-02-SF0725. The authors would like to thank Mr. Idris Zulkifle from School of Applied Physics, Universiti Kebangsaan Malaysia for silver sputtering. The authors would also like to acknowledge Mr. Mohamad Hasnul Naim Abd Hamid and Mr. Muhammad Nazrul Zahari, both from Centre Research and Instrumentation Management (CRIM), Universiti Kebangsaan Malaysia, for FESEM and AFM characterizations, respectively.

\section{References}

[1] G. Li, R. Zhu, and Y. Yang, "Polymer solar cells," Nature Photonics, vol. 6, pp. 153-161, 2012.

[2] G. Yu, J. Gao, J. C. Hummelen, F. Wudl, and A. J. Heeger, "Polymer photovoltaic cells: enhanced efficiencies via a network of internal donor-acceptor heterojunctions," Science, vol. 270, no. 5243, pp. 1789-1791, 1995.

[3] J. Y. Kim, K. Lee, N. E. Coates et al., "Efficient tandem polymer solar cells fabricated by all-solution processing," Science, vol. 317, no. 5835, pp. 222-225, 2007.

[4] W. H. Kim, A. J. Mäkinen, N. Nikolov, R. Shashidhar, H. Kim, and Z. H. Kafafi, "Molecular organic light-emitting diodes using highly conducting polymers as anodes," Applied Physics Letters, vol. 80, no. 20, pp. 3844-3846, 2002.

[5] M. P. de Jong, L. J. van Ijzendoorn, and M. J. A. de Voigt, "Stability of the interface between indium-tin-oxide and poly(3,4-ethylenedioxythiophene)/poly(styrenesulfonate) in polymer light-emitting diodes," Applied Physics Letters, vol. 77, no. 14, pp. 2255-2257, 2000.

[6] M. Jørgensen, K. Norrman, and F. C. Krebs, "Stability/degradation of polymer solar cells," Solar Energy Materials and Solar Cells, vol. 92, no. 7, pp. 686-714, 2008.
[7] F. Zhang, X. Xu, W. Tang et al., "Recent development of the inverted configuration organic solar cells," Solar Energy Materials and Solar Cells, vol. 95, no. 7, pp. 1785-1799, 2011.

[8] Y. Sun, J. H. Seo, C. J. Takacs, J. Seifter, and A. J. Heeger, "Inverted polymer solar cells integrated with a lowtemperature-annealed sol-gel-derived $\mathrm{ZnO}$ film as an electron transport layer," Advanced Materials, vol. 23, no. 14, pp. 1679-1683, 2011.

[9] A. K. K. Kyaw, X. W. Sun, C. Y. Jiang, G. Q. Lo, D. W. Zhao, and D. L. Kwong, "An inverted organic solar cell employing a solgel derived $\mathrm{ZnO}$ electron selective layer and thermal evaporated $\mathrm{MoO}_{3}$ hole selective layer," Applied Physics Letters, vol. 93, no. 22, Article ID 221107, 3 pages, 2008.

[10] S. K. Hau, H. L. Yip, N. S. Baek, J. Zou, K. O’Malley, and A. K. Y. Jen, "Air-stable inverted flexible polymer solar cells using zinc oxide nanoparticles as an electron selective layer," Applied Physics Letters, vol. 92, no. 25, Article ID 253301, 3 pages, 2008.

[11] D. C. Lim, W. H. Shim, K. D. Kim et al., "Spontaneous formation of nanoripples on the surface of $\mathrm{ZnO}$ thin films as hole-blocking layer of inverted organic solar cells," Solar Energy Materials and Solar Cells, vol. 95, no. 11, pp. 3036-3040, 2011.

[12] S. R. Ferreira, R. J. Davis, Y. J. Lee, P. Lu, and J. W. P. Hsu, "Effect of device architecture on hybrid zinc oxide nanoparticle:poly(3hexylthiophene) blend solar cell performance and stability," Organic Electronics, vol. 12, no. 7, pp. 1258-1263, 2011.

[13] M. Y. Lin, C. Y. Lee, S. C. Shiu et al., "Sol-gel processed CuOx thin film as an anode interlayer for inverted polymer solar cells," Organic Electronics, vol. 11, no. 11, pp. 1828-1834, 2010.

[14] N. Sekine, C. H. Chou, W. L. Kwan, and Y. Yang, "ZnO nanoridge structure and its application in inverted polymer solar cell," Organic Electronics, vol. 10, no. 8, pp. 1473-1477, 2009.

[15] M. N. Shan, S. S. Wang, Z. Q. Bian, J. P. Liu, and Y. L. Zhao, "Hybrid inverted organic photovoltaic cells based on nanoporous $\mathrm{TiO}_{2}$ films and organic small molecules," Solar Energy Materials and Solar Cells, vol. 93, no. 9, pp. 1613-1617, 2009.

[16] R. Steim, S. A. Choulis, P. Schilinsky, and C. J. Brabec, "Interface modification for highly efficient organic photovoltaics," Applied Physics Letters, vol. 92, no. 9, Article ID 093303, 3 pages, 2008.

[17] T. Kuwabara, T. Nakayama, K. Uozumi, T. Yamaguchi, and K. Takahashi, "Highly durable inverted-type organic solar cell using amorphous titanium oxide as electron collection electrode inserted between ITO and organic layer," Solar Energy Materials and Solar Cells, vol. 92, no. 11, pp. 1476-1482, 2008.

[18] C. Waldauf, M. Morana, P. Denk et al., "Highly efficient inverted organic photovoltaics using solution based titanium oxide as electron selective contact," Applied Physics Letters, vol. 89, no. 23, Article ID 233517, 3 pages, 2006.

[19] G. D. Sharma, J. A. Mikroyannidis, and S. P. Singh, "Efficient bulk heterojunction solar cells based on D-A copolymers as electron donors and PC70BM as electron acceptor," Materials Chemistry and Physics, vol. 135, no. 1, pp. 25-31, 2012.

[20] H. H. Liao, L. M. Chen, Z. Xu, G. Li, and Y. Yang, "Highly efficient inverted polymer solar cell by low temperature annealing of $\mathrm{Cs}_{2} \mathrm{CO}_{3}$ interlayer," Applied Physics Letters, vol. 92, no. 17, Article ID 173303, 3 pages, 2008.

[21] Z. Q. Xu, J. P. Yang, F. Z. Sun, S. T. Lee, Y. Q. Li, and J. $\mathrm{X}$. Tang, "Efficient inverted polymer solar cells incorporating doped organic electron transporting layer," Organic Electronics, vol. 13, no. 4, pp. 697-704, 2012.

[22] M. Lira-Cantu and F. C. Krebs, "Hybrid solar cells based on $\mathrm{MEH}-\mathrm{PPV}$ and thin film semiconductor oxides $\left(\mathrm{TiO}_{2}, \mathrm{Nb}_{2} \mathrm{O}_{5}\right.$, 
$\mathrm{ZnO}, \mathrm{CeO}_{2}$ and $\mathrm{CeO}_{2}-\mathrm{TiO}_{2}$ ): performance improvement during long-time irradiation," Solar Energy Materials and Solar Cells, vol. 90, no. 14, pp. 2076-2086, 2006.

[23] S. Han, W. S. Shin, M. Seo, D. Gupta, S. J. Moon, and S. Yoo, "Improving performance of organic solar cells using amorphous tungsten oxides as an interfacial buffer layer on transparent anodes," Organic Electronics, vol. 10, no. 5, pp. 791-797, 2009.

[24] L. Vayssieres, "Growth of arrayed nanorods and nanowires of $\mathrm{ZnO}$ from aqueous solutions," Advanced Materials, vol. 15, no. 5, pp. 464-466, 2003.

[25] K. Takanezawa, K. Hirota, Q. S. Wei, K. Tajima, and K. Hashimoto, "Efficient charge collection with $\mathrm{ZnO}$ nanorod array in hybrid photovoltaic devices," Journal of Physical Chemistry C, vol. 111, no. 19, pp. 7218-7223, 2007.

[26] C. Y. Chou, J. S. Huang, C. H. Wu, C. Y. Lee, and C. F. Lin, "Lengthening the polymer solidification time to improve the performance of polymer/ZnO nanorod hybrid solar cells," Solar Energy Materials and Solar Cells, vol. 93, no. 9, pp. 1608-1612, 2009.

[27] B. K. Crone, I. H. Campbell, P. S. Davids, and D. L. Smith, "Charge injection and transport in single-layer organic lightemitting diodes," Applied Physics Letters, vol. 73, no. 21, pp. 3162-3164, 1998.

[28] W. J. Lee, H. Okada, A. Wakahara, and A. Yoshida, "Structural and photoelectrochemical characteristics of nanocrystalline $\mathrm{ZnO}$ electrode with Eosin-Y," Ceramics International, vol. 32, no. 5, pp. 495-498, 2006.

[29] M. S. White, D. C. Olson, S. E. Shaheen, N. Kopidakis, and D. S. Ginley, "Inverted bulk-heterojunction organic photovoltaic device using a solution-derived $\mathrm{ZnO}$ underlayer," Applied Physics Letters, vol. 89, no. 14, Article ID 143517, 3 pages, 2006.

[30] H. Kim, J. Y. Kim, K. Lee, Y. Park, Y. Jin, and H. Suh, “Organic photovoltaic cells based on conjugated polymer/fullerene composites," Current Applied Physics, vol. 1, no. 2-3, pp. 139-143, 2001.

[31] C. T. Chen, F. C. Hsu, S. W. Kuan, and Y. F. Chen, "The effect of $\mathrm{C} 60$ on the $\mathrm{ZnO}$-nanorod surface in organicinorganic hybrid photovoltaics," Solar Energy Materials and Solar Cells, vol. 95, no. 2, pp. 740-744, 2011.

[32] G. Li, V. Shrotriya, Y. Yao, J. Huang, and Y. Yang, "Manipulating regioregular poly(3-hexylthiophene): [6,6]-phenyl-C 61butyric acid methyl ester blends-route towards high efficiency polymer solar cells," Journal of Materials Chemistry, vol. 17, no. 30, pp. 3126-3140, 2007.

[33] P. H. Chen, H. H. Chen, R. Anbarasan, and L. S. Kuo, "Synthesis and characterization of Eosin Y functionalized MWCNT," in Proceedings of the 4th IEEE Nanotechnology Materials and Devices Conference (NMDC '10), pp. 325-327, Monterey, Calif, USA, October 2010.

[34] D. Bi, F. Wu, Q. Qu et al., "Device performance related to amphiphilic modification at charge separation interface in hybrid solar cells with vertically aligned $\mathrm{ZnO}$ nanorod arrays," Journal of Physical Chemistry C, vol. 115, no. 9, pp. 3745-3752, 2011.

[35] D. C. Olson, Y. J. Lee, M. S. White et al., "Effect of polymer processing on the performance of poly(3-hexylthiophene)/ZnO nanorod photovoltaic devices," Journal of Physical Chemistry C, vol. 111, no. 44, pp. 16640-16645, 2007.

[36] J. K. B. Thomas, V. Yana, L. Zhe, K. Dinesh, H. F. Richard, and R. M. Christopher, "White-light bias external quantum efficiency measurements of standard and inverted P3HT:PCBM photovoltaic cells," Journal of Physics D, vol. 45, no. 41, Article ID 415101, 2012.

[37] T. W. Lee and O. O. Park, "The effect of different heat treatments on the luminescence efficiency of polymer light-emitting diodes," Advanced Materials, vol. 12, no. 11, pp. 801-804, 2000.

[38] Y. M. Shen, C. S. Chen, P. C. Yang, S. Y. Ma, and C. F. Lin, "Improvement of surface morphology of thin films and performance by applying electric field on P3HT:PCBM based solar cells," Solar Energy Materials and Solar Cells, vol. 99, pp. 263-267, 2012. 

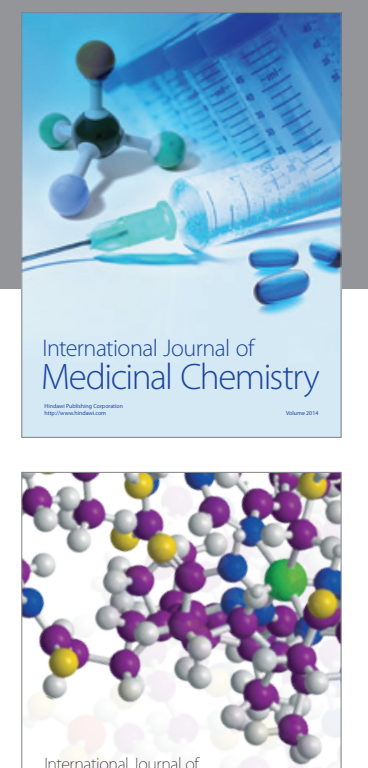

\section{Carbohydrate} Chemistry

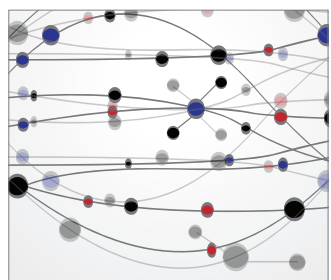

The Scientific World Journal
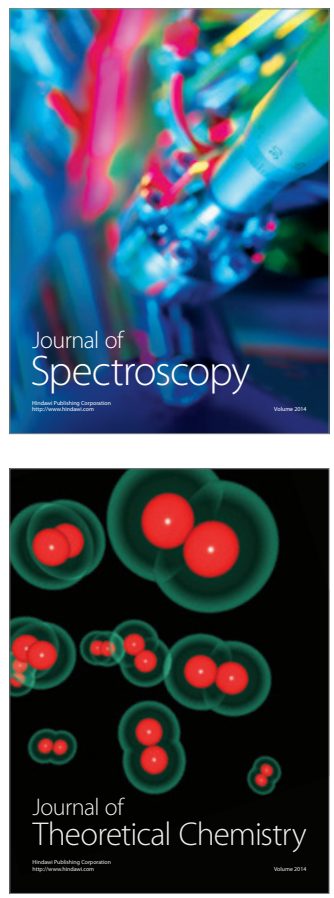
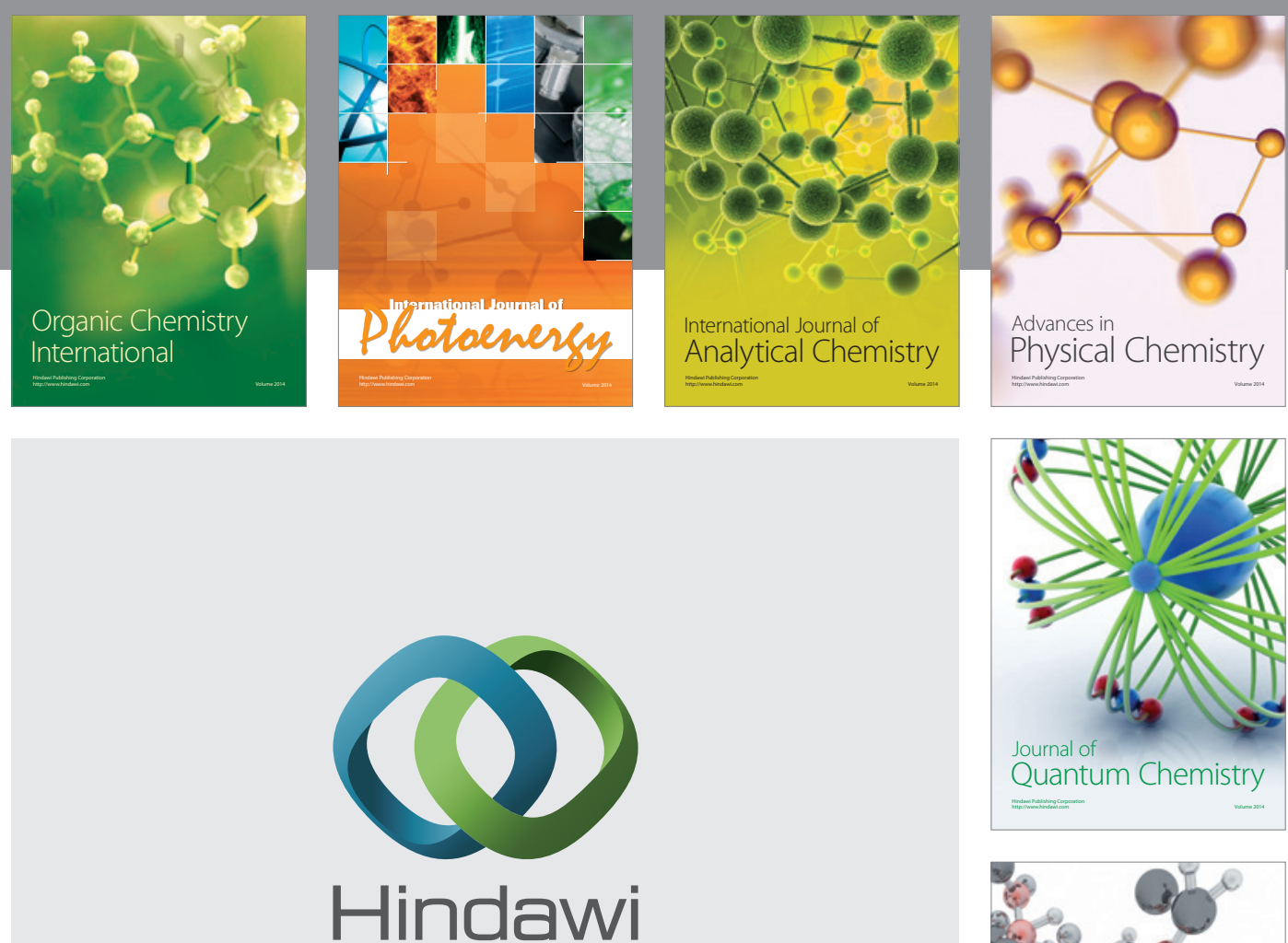

Submit your manuscripts at

http://www.hindawi.com

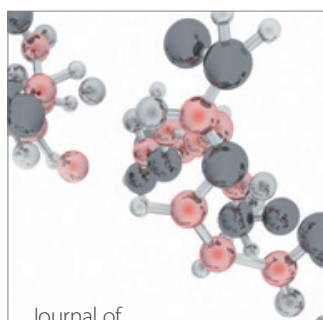

Analytical Methods

in Chemistry

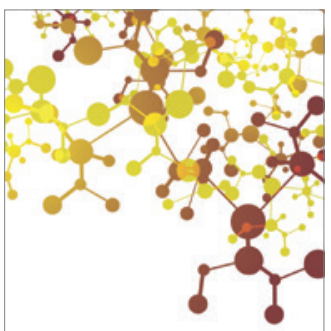

Journal of

Applied Chemistry

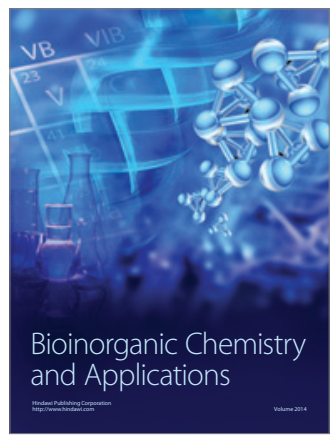

Inorganic Chemistry
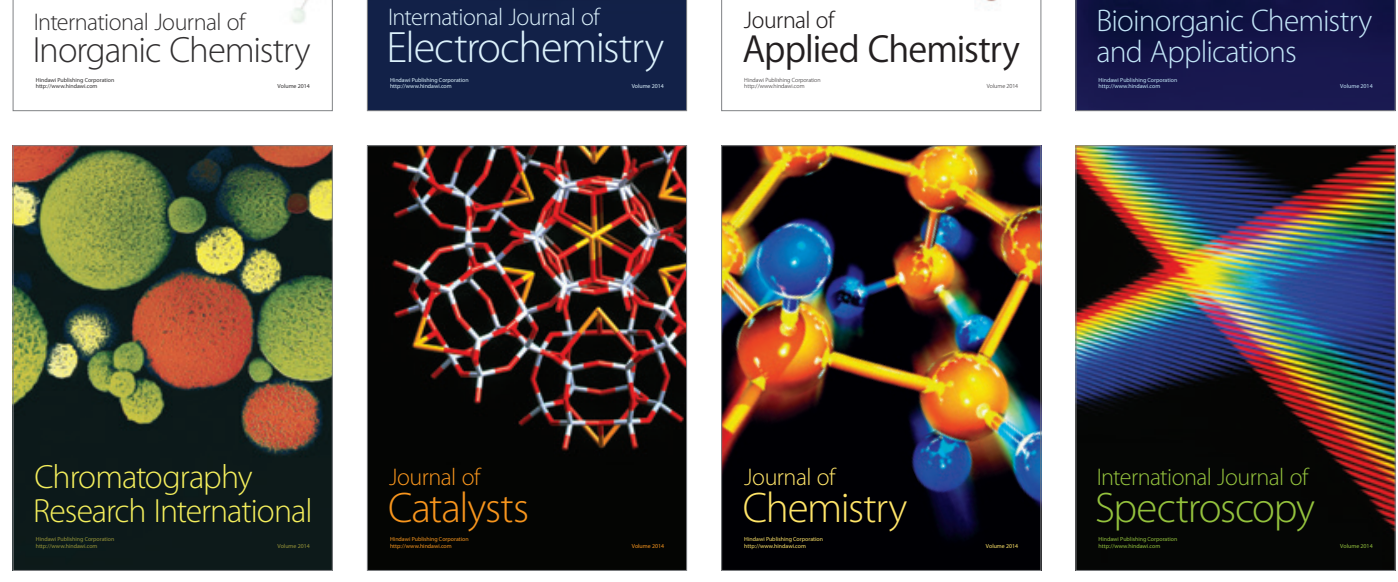